\title{
THE POLICE SPECIAL BRANCH IN COUNTERING THE COMMUNIST PARTY OF MALAYA DURING THE MALAYAN EMERGENCY 1948-1960: AN ANALYSIS OF INTELLIGENCE TACTICS AND STRATEGIES
}

\author{
Amer Fawwaz M. Yazid ${ }^{a}$
}

\begin{abstract}
Malaysia was one of the countries faced with security threat from Communist insurgency inflicted by the Communist Party of Malaya (CPM). The CPM launched their armed revolt on 16 Jun 1948, in the name of war and anti-imperialist struggles against the British Government. The success of the Malayan Security Forces (MSF) during the Malayan Emergency 1948-1960 (the First Malayan Emergency) was based on careful implementation of the Intelligence Services executed by the Police Special Branch (SB), known for its high reputation and efficiency in counter-intelligence details in defeating the insurrection of the CPM. This study aims to explain how the $S B$ utilized their tactics and strategies in countering the CPM subversive activities, specifically during the First Emergency period. It has a vital significance on the studies of intelligence as most of the intelligence tactics and strategies utilized were classified and less highlighted to the public. This study will focus, dissect and extract the roles and functions of the $S B$, primarily on the efficiency of its intelligence strategies and tactics in defeating the CPM movement.
\end{abstract}

Keywords: Malayan Emergency 1948 -1960, Special Branch (SB), Communist Party of Malaya (CPM), Police Intelligence

\section{INTRODUCTION}

This article focuses on the problems encountered by Malaysia (then Malaya) in dealing with the Malayan Emergency 1948-1960 (the First Malayan Emergency). The main focus is to examine the function and roles of the Police Special Branch (SB) in counterinsurgency operations during this period. The SB upheld clear objectives in supplying the Malayan Security Forces (MSF) with adequate, reliable, and sufficient intelligence information on the enemy. Intelligence is a vital element in a guerrilla warfare, serving as a guiding tool for the troops on the field to locate enemies anywhere within their operational area. The intelligence provided by the SB during the First Malayan Emergency may have prevented the loss of lives of the troops involved in the Search and Destroy operations since it provided the forces with safety measures and precautions in searching and eliminating the enemy. Eliminating the enemy through intelligence requires a lot of preparation that involves efficient police strategies and tactics, coordination of combat, as well as decision-making, which in turn, would determine the number of lives lost on the battlefield.

\footnotetext{
a Amer Fawwaz M. Yazid is a Lecturer at the Department of Strategic Studies, Faculty of Defence and Management Studies, National Defence University of Malaysia (UPNM). Email: amerfawwaz@upnm.edu.my
} 
The establishment of the SB marked the turning point for the British counterinsurgency campaign and doctrines during the First Malayan Emergency. The SB had a significant responsibility in protecting and defending the internal security of the country from any subversive revolutionary movement since the beginning of the Emergency period. This study will explain the roles and functions of the SB in eliminating the CPM during this period with the careful implementation of intelligence tactics and strategies emphasized by the Forces. At the same time, this article will also provide adequate highlights on the intelligence tactics and strategies successfully implemented by the SB in countering the CPM movement during the First Malayan Emergency. Most of the existing literatures focus on the policing activities in countries, rather than showing the importance of the police organization in dealing with the subversive and counterinsurgency functions within the nature of the organization.

\section{THE POLICE SPECIAL BRANCH IN THE MALAYAN EMERGENCY 1948- 1960}

The First Malayan Emergency was declared unexpectedly in June 1948, by the British colonial government after insurgents of the CPM killed three British plantation managers in the northern State of Perak. During the initial stage of the Emergency, the SB was seen as weak and unprepared for the CPM armed insurrection. Comber describes the organization as unprepared and slow in providing intelligence activities for the purposes of the military and security benefits in Malaya (Comber, 2008, p.59). In addition, Short also describes the SB's unpreparedness during the early stages of the First Emergency, stating, "The picture from the SB intelligence had too much fuzz as the intelligence information on the ground was low grade, unreliable, and probably stale that it was becoming clearer nothing did so much to find the whole conceptual of the battle itself."(Short, 2000, p. 359).

One of the main roles of the SB was to supply the Army and the MSF with good quality intelligence. This was highlighted by Former Deputy Superintendent (DSP) Chan Kok Kong, when he described the SB's role as "a simple structure of organization that emphasised on the intelligence data collection on the ground against the CPM underground movement inside the jungle from 1948 to 1955" (Chan, April 8, 2016). In fact, as the Emergency proceeded, the flooding of captured Communist documents and other written materials found on their captured agents and from communist jungle base camps had enlightened the organizational task of the SB in decoding the enemy's secret messages, directive letters and orders. All these were advantageous to the collection of valuable intelligence that could be used against the enemy (Reduan Aslie, 1990, p. 177). These messages, if examined closely, provided evidences which could disclose the exact locations of the Communist guerrilla movement, the jungle bases, the food dump, and the meeting places. In certain circumstances, it could also reveal how the Communist secret underground communication operated, as well as their intentions and plans (Short, 2000, p. 363).

The importance of the captured documents of the enemy was well described by Former Superintendent Stephen Gonzago, a former SB field operative who served in the war against the CPM during the First Emergency. Gonzago claimed that, "These documents or whatever written materials found on the field will be kept securely by the SB because within the SB department, they had formed a unit 
comprising of officers who were well trained in Chinese dialects and would be assigned with the task to interpret the captured enemy documents" (Gonzago, April 5, 2016). The captured documents would be filed by the SB Chinese officers, and the first step was to pass the documents to the SB interpreter team. These documents contained a wealth of valuable information, such as the location of the enemy and hidden food dumps (Gomu, April 12, 2016). There may also be intelligence information, for instance, the CPM ambush planning, future sabotage intention, the strength of the CPM Assault Units, locations of meeting places, and the names of Communist logistics suppliers and collectors (Min Yuen)- all the information which could help the SB to greatly neutralize the enemy (Chan, April 8, 2016).

However, the SB faced difficulties when it came to translating secret documents and messages obtained from captured or dead enemies due to the insufficient number of translators, particularly Chinese translators, as in most cases, the materials of the enemy were written in Chinese languages (C.C. Too, 1962, p. 9). In order to tackle this problem, the SB came up with a solution: by working closely with the Psychological Warfare Department, and acknowledging their capability in translating the captured documents of the enemy since they had a number of good Chinese translators working within the department (Lim, 2000, pp. 74-84). Besides having insufficient Chinese translators, the SB also faced problem in acquiring sufficient Chinese personnel (Oong, 2000, p. 180). This transpired during the early stage of the Emergency, when the SB realized that it was not prepared to become the main organization and be in charge of intelligence data collection for the MSF and British Military Forces (BMF).

The major factor that contributed to the insufficient number of Chinese personnel in the SB organization was due to the nature of the Malayan Emergency itself. This period was known as the period of ethnic clash between the Malays and the Chinese, since the MSF was dominated by the Malays, especially, the Police Force. In contrast, the CPM movement was Chinese dominated, and majority of its members were strong supporters of Mao Tse Tung (Dougherty, 1962, p. 303). The Chinese community members in Malaya did not however, agree with the CPM's atrocities in terrorising Malaya with their armed insurrections. The number of Chinese SB officers was scarce even after four years of the SB's establishment (Leong, May 24, 2015).

In reality, to create an effective intelligence organization requires perfect plans and adequate time of implementation of the intelligence training (Kumar Ramakrishna, March 16, 2015). To establish good quality intelligence organization is a hard task, and it requires at least two to three years before the intelligence organization can become fully-fledged, effective and operational (Comber, 2008, p. 61). Inevitably, there would be insufficient capabilities, as shown by the SB, in the early stage of the Emergency. Even though the SB operated with weak conditions, it was clear that they were successful as the first intelligence body during the First Malayan Emergency. 


\section{ELIMINATING THE CPM SUBVERSIVE AND UNDERGROUND MOVEMENT}

The main role of the SB in the First Malayan Emergency was to eliminate the CPM Min Yuen Organization (Clutterbuck, 1973, p. 179). This was the most important objective of the SB, as Min Yuen was a secret underground organization built by the CPM in order to supply their forces with basic necessities such as food, medicine, ammunition, armament and intelligence (Reduan Aslie, 1993, p. 30). Difficulties faced by the SB in locating Min Yuen became evident when the latter started to operate secretly within the society (Reduan Aslie, 1993, p. 30). This meant that anybody could become the CPM Min Yuen agents, for they lived like the public and blended well with the society (C.C. Too, 1962, p. 8). They might be farmers, rubber tappers, villagers, traders, and even small hawkers (Leong, May 24, 2015). The major concern of the SB on these Min Yuen agents was their roles in providing intelligence on the MSF movements (Meor, November 16, 2015). By dressing up as farmers or rubber tappers, the Min Yuen agents might send information regarding the movement of the MSF in the operational area. At the same time, the Min Yuen had their own method of communicating between the organization and their members (Leong, 1998, p. 12). They did not use wireless radio, even though they had had them since World War Two, because it will be easy for the MSF to locate their position through the transmission of radio waves which carried their messages and broadcasts. It might also be possible for the MSF to listen to, and, figure out their secret codes and reveal their plans and intentions (Ismail Saad, 1984, p. 82). For these reasons, the Min Yuen had used a secret communication method - through their Personal Carriers (Clutterbuck, 1973, p.180).

Personal Carriers were communist agents entrusted by the organization to carry and deliver secret directive letters to their main base, jungle bases, and unit commanders. However, not every member can be Personal Carriers for the Min Yuen organization. Only those who were fully trusted by the High Command CPM leaders would be selected for the job (Leong, 1998, p. 17). If necessary, they would be left to die, as their main task was to deliver and protect the security of the secret messages and directives, at all cause, from falling into the hands of the MSF. According to intelligence resources, the secret directive letters normally contained instructions from senior commanders of the CPM to implement future plans, such as assaults and ambushes on the jungle patrols of the MSF, sabotage and espionage activities, as well as other activities that were considered as important to the CPM movements in the country (Leong, 2012, p. 7). Normally, these messages would be written in Chinese, using secret codes and Chinese terms that could be very hard to understand, unless, the reader himself, was a communist (Leong, May 24, 2015). The method of using jungle courier to deliver messages could be executed using variety of ways. On certain occasions, messages would be rolled into tiny slips and hidden in places that were unexpected by the MSF, particularly, when the courier was searched at security roadblocks and checkpoints (Leong, May 24, 2015). Among the most popular methods were to put the rolled slips into bicycle handle grips, or in the sleeves of trousers, or dresses that were properly sealed. The secret directive letters would then be delivered directly to the intended person or by leaving it in a secure place and would be picked up later (Leong, May 24, 2015). 
The main reason for the CPM to use rolled slips was to avoid the exploitation of the information by the SB if the Communist jungle courier was captured by the MSF. The rolled slips contained information on communication often linked from one CPM Assault Unit to another, and were vital information. In order to ensure that their communication security system was protected, from time to time, rolled slips were used to avoid the leakage of the CPM intelligence (Gonzago, April 5, 2016). This was, by far, the toughest task faced by the SB, particularly in locating the secret directive letters. Despite all these, in certain cases, the SB managed to capture Min Yuen jungle couriers. This was a blow to the CPM as the courier might be manipulated and forced by the MSF to disclose their main jungle bases and underground organization during the interrogation process (Meor, November 16, 2015). This was one of the advantages of the Min Yuen communication system, for, once their jungle couriers were captured or killed, their organization would be in danger, as the SB could use the information contained in the directive letters to fight against the CPM movement.

The formation of the SB under the instructions of the BMF was the most appropriate idea, conducted at the most appropriate time in order to defeat the CPM armed insurrection in Malaya during the First Emergency campaign. Many historians and academicians in the strategic and insurgency studies accredited the significance of the roles and function of the SB in providing a successful result on the MSF and the BMF, in the war against the CPM insurgency in Malaya (such as Comber, 2008, p.282; Komer, 1970, p. 3; Short, 2000, pp. 363-364; Leong, 1996, p. 32; and Reduan Aslie, 1993, p. 208). The SB highlighted the importance of the roles of the intelligence, and, was successful in making the CPM vulnerable to the tactics that were carried out by the MSF.

\section{INTELLIGENCE TACTICS AND STRATEGIES OF THE SPECIAL BRANCH DURING THE MALAYAN EMERGENCY 1948-1960}

According to British Intelligence, there were eight main sources of intelligence during the First Malayan Emergency: the Surrendered Enemy Personnel (SEP), the Captured Enemy Personnel (CEP), the captured enemy documents, the identification of the dead Communist, the information supplied by agents and informer, and, by the general public (Clutterbuck, 1966, pp.96-99), the reports by the MSF patrols, the visual air reconnaissance and air photography, and interpretation (ATOM, 1958). These intelligence sources were mainly used for the purpose of locating the enemy's base camps that were hidden in the jungle.

However, one must understand that the task of locating the enemy's base camps was a tough job, even when the MSF had already obtained sufficient intelligence. The reason for this was the intelligence would not necessarily point the exact locations of the CPM jungle base camps, since the enemy's base camps would be moved, from time to time, depending on the level of security, from one place, to another sector, or, another safe area (OPERATIONS-GENERAL, 1957, p. 15). In the early campaigns, it was decided that the task of collecting intelligence sources should be done by the police, rather than by the army. Police intelligence would provide information and details on the whereabouts of the Communist base camps to the army, or, the combat patrol units (Comber, 2008, pp.3-5). Apart from providing adequate supplies of intelligence for the MSF jungle operations, the main concern of 
the SB was to defeat the CPM underground secret organization. The Communist insurgents had a powerful support force in the form of the civilian branch of the Communist subversive organization, known as the "People's Movement", or also known as the famous "Min Yuen" (Reduan Aslie, 1993, p. 30).

In the peak years of the campaign, the Min Yuen maintained essential supply lines to the Communist guerrillas, as well as providing recruits and intelligence services. The Min Yuen's principal weapons were terror and intimidation, with which they controlled the so-called "Massed Organization" which kept them supplied with food, clothing, money and medical supplies (Purcell, 1954, p. 63). However, by 1952, the position of the Min Yuen became increasingly precarious as the Security Forces began to get a measure of them. In the mid-1950s, most of them had changed to active terrorist operations (Chapman, S., 1953, p. 30). When deep jungle operations were initiated by the MSF, the local intelligence on the ground would conduct constant harassment on the enemy's position and clear the jungle before the SB made an ambush (OPERATIONS-GENERAL, 1957, p. 14).

\section{MANIPULATION OF SURRENDERED ENEMY PERSONNEL (SEP) AND CAPTURED ENEMY PERSONNEL (CEP)}

A Surrendered Enemy Personnel, henceforth, known as the SEP, would be a member of the Communist organization, or, a Communist sympathizer, handed over to the MSF or SB operatives during the search and destroy operations. Most of the SEPs surrendered to the MSF due to several factors or reasons, such as, poor living conditions and environment: starvation, morally neglected, afraid of death, and psychological duress (Clutterbuck, 1966, p. 104). Besides that, other factors that contributed to their surrender, included, "Defection to their former organization, the temptation to the government official pecuniary rewards, as well as intention to SelfRenewed and getting back to their society" (Gonzago, April 5, 2016). A surrendered, or, captured SEP, or CEP, was considered as the most valuable asset to the SB, and to the events of the First Malayan Emergency.

The top priority of the SB was to capture the enemies alive as they would be useful in leading to tonnes of valuable intelligence information. The SB always stressed on their officers to put the lives of the enemy as their top priority even when conducting intelligence gathering task (Gonzago, April 5, 2016). Several measures needed to be taken before manipulating the SEP and CEP. First of all, maintaining secrecy: in fact, the general rule was to detain the surrendered enemy, without notifying the public for as long as possible. This could become an advantage for the SB because they might use the SEP, to penetrate the CPM organization, since the enemy did not know that one of their members had been persuaded by the SB. The SB officers would determine whether or not the SEPs would be used in operations, as the SEP must not be used on immediate follow-up operations (ATOM, 1958, p.3).

The second rule was handling. Handling was also known as an interrogation process (ATOM, 1958, p.3). Interrogation process was a vital step for the SB, as the main focus was to extract intelligence information on the SEP's former organization. The information given by the SEP would be "questionable, especially in terms of the accuracy of the stories told to the SB officers who were in charge of the interrogation process" (Chan, April 8, 2016). Normally, the SEP and the CEP, would be 
interrogated by Chinese SB operatives since the CPM members were mainly Chinese and used the Chinese language to communicate with others. Interrogation process held significant objectives for the SB. One of the objectives was for the SB interrogator to gain the trust of the SEP/CEP as they had been indoctrinated by the Communist's radical ideologies for almost all of their lives. In order to gain the enemy's trust, "The SB officers would approach the enemy with good manners, and, as politely as possible, with the purpose of winning the hearts and minds of the SEP since this might be an effective way to build up their trust in the SB interrogators. The interrogation process generally took about 7-14 days, depending on how well the SEP cooperated with the SB" (Gonzago, April 5, 2016).

The accuracy of the information given by the SEP and CEP would depend on how well they cooperated during the interrogation process. The interrogation process was an art that needed various talents and brainwashing skills. It required superb psychological skills in order to turn the SEP to the government's side. The process might take days, weeks, or even months. The procedures of handling the CEP and the SEP were both the same. The CEP member was put in operations within the period of 72 hours after his capture to ensure that the secrecy of the information obtained from the CEP was still relevant before the other members discovered that he was detained by the SB (ATOM, 1958, p.3). During the interrogation process, questions would be conducted based on the position of the members in the force (enemy), and the roles that they take in the former organization. If the captured member was a high ranking officer, the questions would focus on his unit's strengths and activities (Chan, April 8, 2016). There were two sets of pre-determined questions asked by the SB. Examples of the questions were: name, race, and the dialect used by the CEP/SEP, the length of time the SEP had been in the jungle, the SEP's ranks and units, as well as, if there were other CPM members who would want to surrender (ATOM, 1958, p.16 ). If there were, the SEP needed to go back into the jungle and persuade them to surrender, or, go back into the jungle and work for the SB/MSF instead.

Under these circumstances, if the SEP/CEP did not answer the first set of questions, the SB officers who were in charge of the interrogation process would ask the following questions to decide how the SEP could be of use for further operations, such as: How many occupied camps did the SEP know to which he could lead the SF patrols?; Were they occupied?; How long would it take to reach them?; When did he think that his absence would be noticed?; When would the members in the camps were likely to know of his surrender?; Were there any routes likely to be used by the Communist guerrillas in coming into or leaving the camps?; Did the SEP know any kind of arms or food dumps, and, the details of the contents hidden nearby the camps? (ATOM, 1958, p.16). There was no evidence to show that the SB used torture methods as some kind of approach in extracting the information from the enemy during the interrogation process, although, the SB officers might have intended to carry out such deplorable actions (Gonzago, April 5, 2016). However, Clutterbuck highlighted that in some cases, the SB interrogation process were harshly conducted. He mentioned that "The SB interrogation technique was much more subtle than a redhot poker as the victim (enemy suspect) would be put in the dark on a passenger seat of a parked car, and he would be interrogated with a long-slow exhaustion process" (Clutterbuck, 1966, pp. 97-98 ). 
An important lesson obtained from the interrogation process was how well SB interrogators were willing to understand the enemy's way of thinking through their behavioural patterns, mental processes, emotional responses, and psychological beliefs (Clutterbuck, 1966, pp. 97-98) since the SEP/CEP were the CPM's underground organization. An ordinary person would not be able to understand what they had been through before that (C.C. Too, 1962). If the SEP and CEP agreed to be the informer for the government, particularly, the informer for SB, they would be sent to their former organization for intelligence gathering process and to infiltrate them from the inside (Leong, May 24, 2015). Besides that, the SEP or CEP would also work closely with other MSF patrol units, and help them to locate the CPM jungle camps, the location of Dead Letter Boxes (DLB), food dumps, arms dumps, or even identifying dead enemy for intelligence purposes (ATOM, 1958, p.3).

The SEP would be suitable for the job as jungle trackers, and in certain circumstances, they would serve as the jungle tracker for the MSF units in locating their fellow comrades who were well blended and hidden in the society or jungle environments. At the same time, the SEP or CEP would serve as the interpreter for the SB Contingent and Divisional Office (Gonzago, April 5, 2016). They might be given the task to interpret the intelligence data contained within the captured CPM documents. Most of the times, captured documents retrieved from dead enemy bodies would become the "most valuable intelligence information for the SB as it would disclose vital information on the enemy's activities, such as, locations of meeting places for the CPM High Command and State leaders, locations of the food dump and arms dump, time and places of CPM guerrilla units rendezvous points, as well as future intention of the CPM guerrilla units sabotage or assaults activities" (Ghazali Seth, November 17, 2014). Though the captured documents were written in the Chinese language, it was not the same as the Chinese language used in daily communication. Instead, they were written in "secret codes and messages that were only known by certain SEP or CEP who could understand and interpret the contents of the messages" (Leong, May 24, 2015). This demonstrated that the cooperation between the SEP/CEP and the MSF was one of the most important parts of the war against the CPM.

\section{THE SPECIAL BRANCH AND THE IMPLEMENTATION OF HUMAN INTELLIGENCE}

Besides manipulating the SEP and CEP, the SB also used the method of establishing listening posts, and employment of SB agents and informers to infiltrate the CPM's underground organization. Listening posts would be the SB's informers who might have connections with the CPM guerrillas or sympathizers (Chan, April 8, 2016). Their main task was to identify the movement or intention of the enemy organization. Besides that, they might be able to "locate the position of the enemy's jungle base camp through their connections with the enemy members, as the Communist guerrilla would not notice that one of their friends was a government agent" (Gonzago, April 5, 2016).

There were certain criteria that were considered by the SB in selecting persons to become agents for their listening posts. The listening posts would normally be a static position where the SB agents could monitor the movement of the enemy agents and their sympathizers. However, the chosen person must be "humble, and can mix 
easily with their surroundings as the only way for them to retrieve intelligence information was through verbal conversations with the locals" (Gonzago, April 5, 2016). At the same time, during the First Malayan Emergency, the SB also used the blackmailing method on certain individuals who might have a link to the CPM organization in order to force them to serve as listening posts for the SB. However, intelligence data collected through blackmailing method might not be genuine, as the cooperation of the source could be doubtful (Gonzago, April 5, 2016).

Several strategic locations were chosen by the SB to employ the static position of their listening posts. Among the popular locations were places with high public concentration, such as villages, towns, main markets, restaurants, social clubs, Chinese temples and New Villages, including aborigine's compound (Leong, May 24, 2015). Those locations were chosen due to the higher chances of the listening posts to make contact with the CPM guerrilla members as most of the times, the CPM guerrillas would be at these locations to conduct meetings with their fellow comrades, resupply logistical needs such as food and medication, or even to obtain intelligence from the locals regarding the movement of the MSF in that particular area. The application of listening posts had certain advantages and disadvantages when it came to the strategical point of view. The advantages of listening post were : easy to set up at any location since the SB did not have to deploy their own personnel to carry out the job, and at the same time, anyone could be suitable for the job, such as villagers, aborigines, hawkers, traders, and even in some cases, beggars (Gonzago, April 5, 2016).

Nevertheless, its disadvantages included the accuracy of the intelligence information which may be doubtful. This was due to the fact that there were several consequences that might jeopardize the accuracy of the listening posts. Based on the intelligence manuals, the information retrieved from the listening posts was mainly through verbal communication and the reliability of information might be less accurate due to problems of noise: the accuracy of the information does not tally with the actual events, as the information might be based on rumours or stories created by the surrounding environment, such as gossips or prediction (Gonzago, April 5, 2016). Furthermore, there were two types of information delivery: Consciousness delivery the situation when a person would tell information to the listening post according to their own will, and not, under duress - a rare situation for the Communist guerrillas (ATOM, 1958, p.3). Another type of delivery was the unconscious delivery. In most cases however, the information was given through unconscious delivery - a situation where a person revealed their secret or information without realising that it would compromise their movement, which was an advantage to the receiver of the messages (ATOM, 1958, p.25). For example, "A CPM member unexpectedly met his old friends at a restaurant. Without knowing that one of his friends was now the SB informer, he told them about the CPM's subversive activities. However, information obtained unconsciously were often deemed as unreliable and inaccurate, as the SB's listening posts possibly, did not have a clear mental picture of the information given by the sender" (Leong, May 24, 2015).

\section{CONCLUSION}

The First Malayan Emergency had significantly shown that the SB was unprepared, weak, and poor in providing the MSF with reliable intelligence information in the 
initial stage. However, despite the problems of poor equipment, organizational management, logistics, insufficient training and various other challenges, the SB had proven to be efficient and effective since they learnt from their weaknesses and previous mistakes. The SB has evolved by concentrating on the training of their officers and operatives in order to build up the degree of quality of intelligence gathering on the field through the formation of the SB Training School in Kuala Lumpur.

Besides focusing on the training module of intelligence and counterintelligence, the SB had also developed various new strategies and tactics in counterintelligence to fight against the CPM underground movement, particularly, the Min Yuen Organization. Among the strategies and tactics were the deployment of SB agents, informers, and listening posts which were scattered across the Malayan fields in order to enable the Police Force to infiltrate the enemy's organization effectively. Nevertheless, among the key to the success of the SB during the Malayan First Emergency was the manipulation of the Surrendered Enemy Personnel and the Captured Enemy Personnel (SEP/CEP). The SEP and CEP had significantly contributed to the progress in leading the SB throughout the process of eliminating the enemy by providing first degree quality intelligence to the SB. However, to obtain the SEP/CEP's attention and cooperation to serve the SB was rather challenging, particularly during the interrogation process by the SB. It required time consuming interrogation sessions and high degree of patience on the part of the SB interrogators in order to obtain the trust of the SEP (winning the hearts and mind of the guerrillas) so that they would agree to cooperate.

The art of interrogation was also the most important step taken by the SB to turn the SEP/CEP to their sides. The SEP and CEP also contributed significantly in terms of translating captured enemy documents which were written in secret codes and messages. Apart from their job in translating captured documents, the SEP also played vital roles as jungle trackers to locate their former jungle base locations, identifying dead enemies and locating enemy's hidden food dump in the harsh Malayan jungle. Although the SB faced greater difficulty during the First Malayan Emergency, they had proven that despite all the weaknesses and challenges, they managed to be successful in defeating the CPM insurrection within a short period of time, considering the fact that the Communist armed insurrection posed a number of tough problems.

Looking back at the historical functions of Police Special Branch, the SB has shown significant importance in developing intelligence tactics and strategies particularly countering subversive elements within a country. Counterinsurgency doctrines that were utilized by most of the Superpowers, such as the United States in the Vietnam War, were based on military intelligence. Nevertheless, the United States had failed and lost in the campaign. However, from the British perspectives of intelligence doctrines, they have proven that Police organizations were also capable in providing the intelligence that was needed in the critical events of the Malayan Emergency 1948-1960. This has changed the perspectives towards the Police organization, whereby, if somehow the Police Forces were to be utilized wisely, they possess similar capabilities in defending the security of a nation, identical to that of the military organization. 
The success of the Police SB in the First Malayan Emergency campaign as the main organization supplying intelligence to the armed and friendly forces, had significantly shown that the SB was on the right track in the implementation of various intelligence tactics and strategies. We must accept the fact that during armed conflicts, intelligence will be needed in order to know and understand your enemies. The Algerian conflicts which involved the French was a stalemate as the French Armed Forces had failed to carry out the correct intelligence tactics and strategies. The Americans had issues in Vietnam as they were not totally focusing on the quality of the intelligence information, but instead, stressing on the firepower and maximum forces in their counterinsurgency doctrines.

The SB had demonstrated good reputations and skills in eliminating the Communists during the First Malayan Emergency as only a few countries had succeeded in fighting a guerrilla warfare in world history. Among the vital factors achieved by the MSF was their access to higher quality intelligence information provided by the SB. The SB was the key factor to Malaya's success in fighting against the Communists during the Emergency. Since half a decade ago, the SB has shown significant development in carrying out their roles and functions in intelligence operations. Though the unit had faced a lot of challenges, including insufficient manpower, and various assassinations of SB personnel, the SB had played a huge role in defending the country from subversive threats posed by the enemies. In other words, the SB was the key factor for Malaysia to be successful in their counterinsurgency campaigns. In contrast, the Americans had failed in the Vietnam War, which was similar to Malaysia's background from the counterinsurgency and insurgency perspectives. The SB exists until today where it serves under the supervision of the Royal Malaysian Police Headquarters, in Bukit Aman, Kuala Lumpur.

The SB had improved its organizational strengths in terms of their capability in fighting terrorism. The SB had learned well from their past experience on their counterinsurgency operations during the First (and Second) Emergency. Even up to this day, the SB still protects our country from threats such as those posed by the Islamic State Movement (IS) that continuously impinge on our country's domestic and internal security. Through the collection of high quality intelligence and surveillance systems, the SB has proven to be the best agent in gathering enemy's intelligence since the First Malayan Emergency, with the help of other branches of the Armed Forces. The SB still operates today to protect Malaysian borders from terrorist attacks such as the bombing incidents in Bangkok, Jakarta, and the Philippines executed by IS militants. Based on these incidents, it is clear that IS militants have targeted the Southeast Asian Region as their operational bases to evoke terrorism. The $\mathrm{SB}$ is proven to still be efficient, in the sense that they had prevented these terrorist bomb attacks from occuring in Malaysia. As a matter of fact, a number of IS militant members were arrested by the SB before they even had the chance to attack the capital city of Kuala Lumpur. This goes to show that despite the enemy being different from the CPM, the tactics employed from the Emergency periods are still relevant and effective in overcoming the threats posed by IS militants. 


\section{ACKNOWLEDGEMENTS}

The Author would like to thank the following individuals for their help in the completion of this article: General Tan Sri Datuk Amar Mohd Ghazali Mohd Seth (Retired), SAC Datuk Dr. Leong Chee Woh (Retired), SUPT. Stephen Gonzales Gonzago (Retired), DSP Chan Kok Kong (Retired), ASP Meor Roslan Dato' Meor Jaafar (Retired), ASP Salleh Gomu (Retired), Associate Professor Dr. Kumar Ramakrishna, Dr. Noraini Zulkifli, and Mr. Azrul Azlan Abdul Rahman.

\section{REFERENCES}

Arkib Negara Malaysia, 1957/0537801 “Operations-General”, 1957/0537801.

Aslie, M. R. (1990). Tan sri Mohd Haniff Omar: Kepolisan dan keselamatan. Kuala Lumpur: AMK Interaksi Sdn. Bhd

Aslie, M. R. (1993). Pemberontakan bersenjata komunis di Malaysia. Kuala Lumpur: Dewan Bahasa dan Pustaka.

Chapman, S. F. (1953). The jungle is neutral. London: Chatto \& Windus.

Clutterbuck, R. (1963). Riot and revolution in Singapore and Malaya 1945-1963. London: Faber \& Faber.

Clutterbuck, R. (1966). The long long war: The emergency in Malaya 1948-1960. London: Cassel.

Comber, L. (2008). Malaya's secret police 1945-1960: The role of the special branch in the Malayan emergency. Singapore: Institute of South East Asia Studies.

Dougherty, J. E. (1962). They call the guerrilla war in Malay. In F. M. Osanka (Eds.), Modern guerrilla warfare: Fighting communist guerrilla movements 1941-1961 (p.303). New York: Free Press.

Komer, R. W. (1972). The Malayan emergency in retrospect: Organization of a successful counterinsurgency effort - A Report prepared for advanced research projects agency. Santa Monica : RAND Corporation.

Leng, L. C. (2000). The story of a psy-warrior tan sri dr. C. C. Too. Batu Caves, Selangor: LCL Publications.

Oong, H.C. (2000). The Chinese politics in Malaya 1942-1955: The dynamics of British policy. Bangi: UKM Press.

Purcell, V. (1954). Malaya: Communist or free? London: Victor Gollanz.

Saad, I. (1984). The CPM revolt: Why fail? In Khoo Kay Kim \& Aznan Nawang (Eds.), “Darurat 1948-1960” (p. 84). Kuala Lumpur: Muzium Angkatan Tentera.

Short, A. (2000). In pursuits of mountain rats: The communist insurrection in Malaya. Singapore: Cultured Lotus. 
The conduct of anti-terrorist operations in Malaya (ATOM). Director of Operations Malaya, 1958, Restricted.

Too, C. C. (1962). Psychological warfare and some aspects of the psychology of the people in Southeast Asia in areas where communist insurrection is likely to arise. Arkib Negara Malaysia: 2008/0000241.

Woh, L. C. (1996). Scorpio the communist eraser. USA: Rocky Mountain Press.

Woh, L. C. (1998). Scorpio against the one-eyed dragon. USA: Rocky Mountain Press.

Woh, L. C. (2012). Scorpio on the dragon demise: The second Malayan communist insurgency emergency 1970-1990. USA: Rocky Mountain Press.

\section{Interviews}

Interview with Associate Professor Dr. Kumar Ramakrishna, Head Centre of Excellence for National Security, S. Rajaratnam School of International Studies, Nanyang Technological University, Singapore, on 16 March, 2015.

Interview with DSP Chan Kok Kong, Former Special Branch Staff Officer E1A (SB Communist Underground Sections) (1951-1984), at Bandar Menjalara, Kepong, Selangor, on 8 April 2016.

Interview with Former ASP Salleh Gomu, Former Special Branch Staff Officer E1A (SB Communist Underground Sections) (1967-1977) at Wangsa Maju, Kuala Lumpur, on 12 April 2016.

Interview with General Tan Sri Datuk Ghazali Seth, former Malaysia Chief of Armed Forces (1981-1986) at Phileo Damansara, Petaling Jaya on 17 November 2014.

Interview with Meor Roslan Dato' Meor Jaafar, former Assistant Superintendent Police (ASP), and, former Police Special Branch operatives (1978-1984), at Sungai Besi, Kuala Lumpur, on 16 November 2015.

Interview with SAC Datuk Dr. Leong Chee Woh, Former Deputy Director of Royal Malaysia Police Special Branch (1981-1984) at Bandar Tun Hussein Onn, Cheras, on 24 May 2015.

Interview with Superintendent Stephen Kingsford Gonzago, Former SB operatives and Commander of Bukit Aman Special Branch E3M (Special Tactics and Operations) (1956-1992), at Bandar Utama, Petaling Jaya, Selangor, on 5 April 2016. 